\title{
DETECTION OF THE PARASITES WHICH INFECT THE PIGEONS IN THE SHARQAT CITY, SALAH AL-DEEN PROVINCE
}

\author{
A. UL-JABBAR M.H. ALJOBURI; N.A. JASSIM and ISMAEL I. HASAN \\ Faculty of Veterinary Medicine, University of Tikrit, Iraq.
}

Received: 30 December 2018; Accepted: 15 January 2019

\begin{abstract}
The study was designed to detect the parasites that affect the bathroom (males and females) in different areas of the Sharqat city, Salah Al- Deen province. The study used (74 pigeons). The results of the presence of ten types of parasites with percentages: Raillietina tetragona $12(16.2 \%)$, among the pigeons. Other parasites encountered included; Raillietina echnobothrida. 10(13.5\%), Ascaridia columbae 9(12.1\%), Capillaria spp 9(12. 2\%), Argas persicus 8(10.8\%), Menopon gallinae 7(9.4\%), Columbicola columbae 7(9.5\%), Eimeria spp 6(8.1\%), Leucocytozoon spp 4(5.5\%), and Haemoproteus spp 2(2.8\%). We concluded from this study that pigeons with different types of parasites (internal and external) recorded the highest parasitic infection Raillietina tetragona.
\end{abstract}

Key words: Parasites, Pigeons, City of Sharqat, Salah Al-Deen province.

\section{INTRODUCTION}

Pigeons one of bird species which found of ancient times, it adapted worldwide to live in areas around the cities and they everywhere in urban environments (Natala et al., 2009). It is widely distributed in the world including Iraq, in some countries the pigeon are used for human food as well as ornamental purposes (Klein, 2008, Vazquez et al., 2010). Pigeons are kept in Iraq for ornamental purposes, therefore pigeons we breeded like other precious birds in the urban areas despite pigeon are considered as a serious health problem for human due to diseases transport (Sari, 2008, Zangana, 1982). It may be responsible for carry some pathogens as Newcastle disease, Salmonella and Aspergillus (AlJumaily, 1989). Pigeon infestations by external parasites (Lice \& mites) which may be responsible for decrease power flight of bird's, due to produced perforate the large wing- and tail-feathers which help them to increase lost areas from the wing surface, lower flight efficiency and, it may help to transport agents of diseases by suck the blood (Radfar et al., 1989, Marques, 2007). Pigeons are infected by various numbers of gastrointestinal parasites and blood parasites which considered as a dangerous and life threatening and cause illness for it (Gilik and Arslan, 2011, Adang et al., 2008). Aimed the study for determined presence of external parasites,

Corresponding author: A. UL-JABBAR M.H. ALJOBURI E-mail address: abduljbbar81n@gmail.com

Present address: Faculty of Veterinary Medicine, University of Tikrit, Iraq. gastrointestinal parasites and blood parasites which infected the pigeons in the Sharqat city, Salah AlDeen province.

\section{MATERIALS AND METHODS}

Collection of 145 pigeons (Columba livia domestica) from local market at the Sharqat city, these samples consist of $\{34\}$ adult males and 40$\}$ adult females during the period from February to May 2018. The skin and the feathers were examined with the naked eye and using the magnifying glass from the head to the feet and through the neck, wings and thighs to isolate the external parasites. The digestive system was taken of the pigeons immediately after slaughter and examined the contents of the intestine to detect the internal parasites and wash the intestinal mucosa with the physiological solution to isolate and collect the attached worms (Al-Hubity and Al-Habib, 1979, McDougald, 2003). The different parasites were identified according to (Soulsby, 1982). The pigeons feces was taken and examinated in laboratory carried out using the buoyancy method to search for cylindrical and striped eggs and the deposition method to detect the eggs (Charles, 1998). Collected the blood samples by using the disposable syringes of insulin for blood draw through a brachial vein. Each sample provided two blood smears, fixed with methanol and stained with Quick Panoptic and Giemsa dyes according to (Foronda et al., 2004). The slides were examined under light microscopy by using oil immersion lenses as described by (Soulsby, 1986).

$\{74\}$ pigeons samples infected 


\section{RESULTS}

The results of this study can be illustrated from the following figures and tables

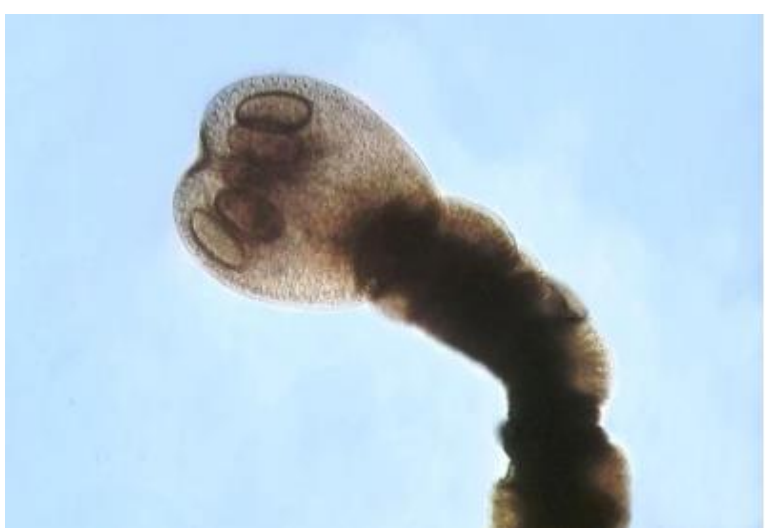

Fig.(1) Scolex of Raillietina tetragona $x 40$

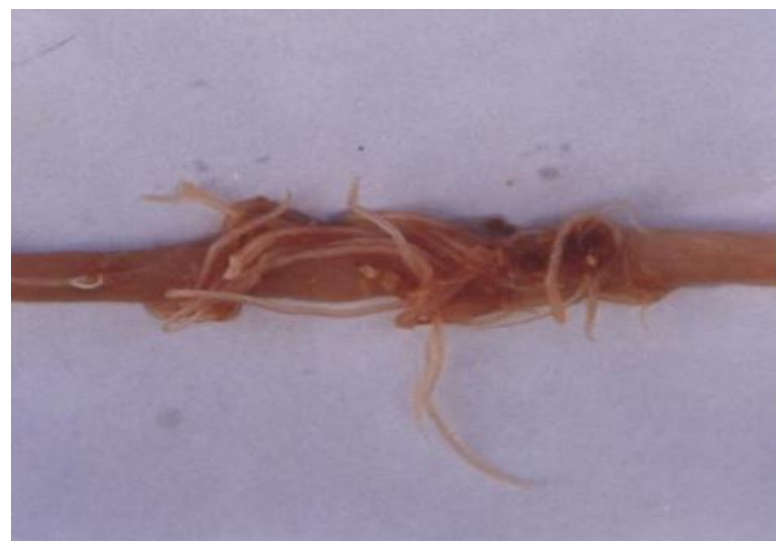

Fig. (3) Ascaridia columbae

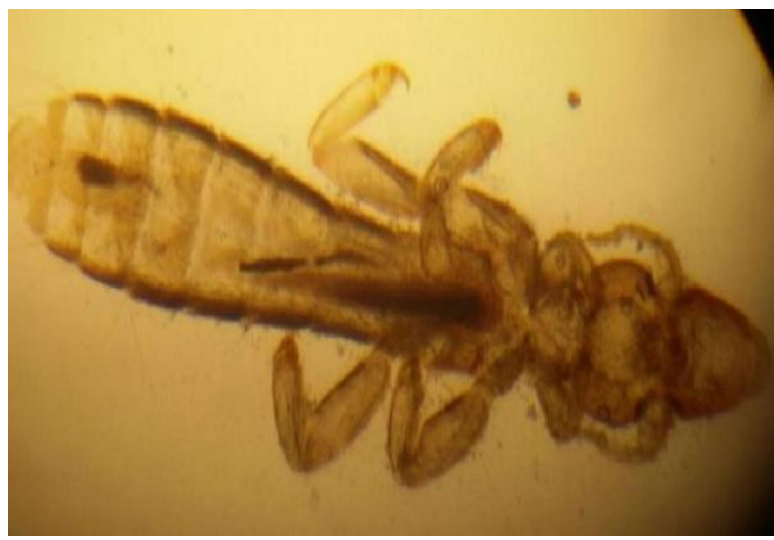

Fig. (5) Columbicola columbae $\mathrm{x} 40$

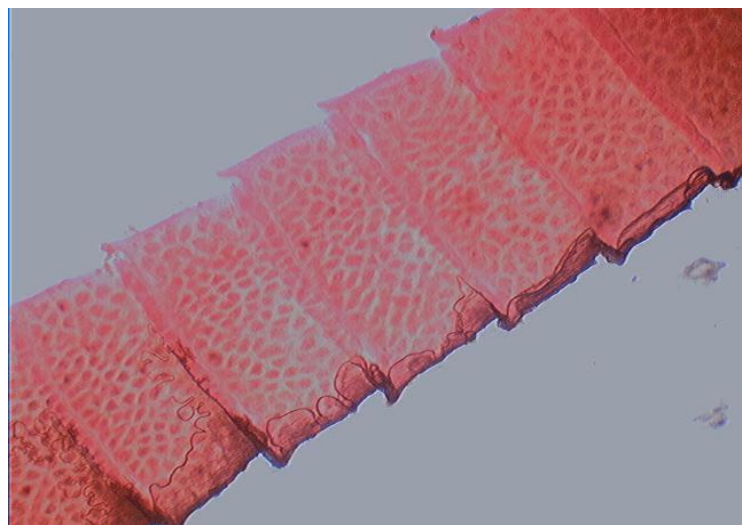

Fig.(2) R. tetragona gravid segment $x 40$

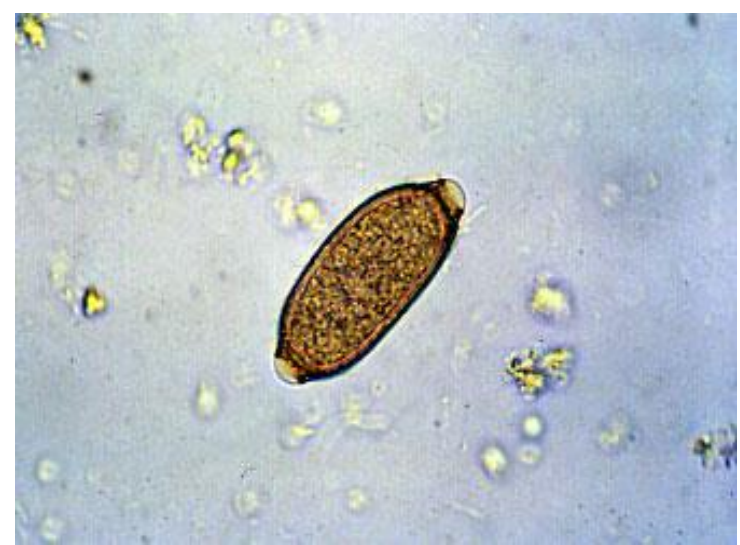

Fig. (4) Capillaria spp. $\mathrm{x} 40$

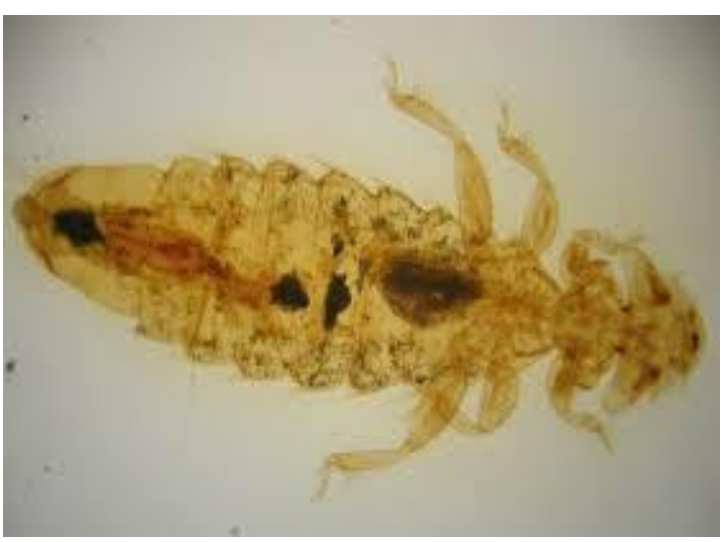

Fig. (6) Menopon gallinae x40 


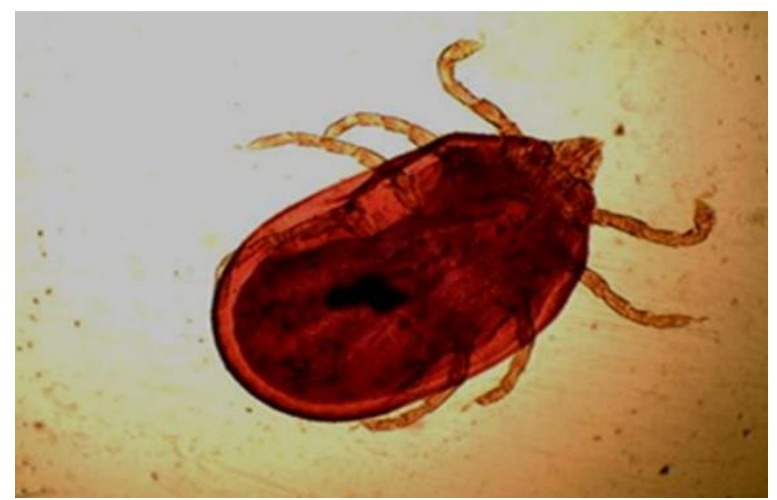

Fig. (7) Soft tick (Argas persicus) x40

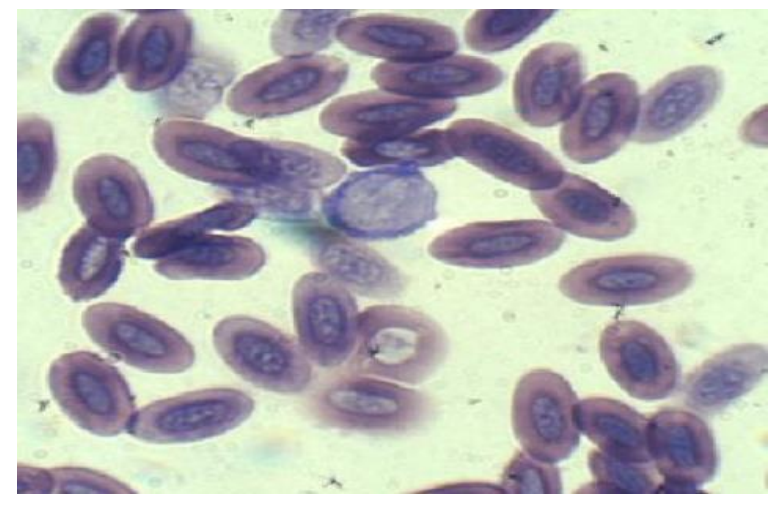

Fig. (9) Leucocytozoon spp x100

This study recorded that different types of (internal and external) parasites species in both males \& females of Pigeons (Columba livia domestica) collecting specimens from different locations in Sharqat city infected by single infestation in males $15(20.3 \%)$ and mixed infestation $17(23.1 \%)$, but in females single infestation $22(31 \%)$ and mixed infestation 19(25.6\%) (Table -1). Raillietina tetragona was found to be the most prevalent

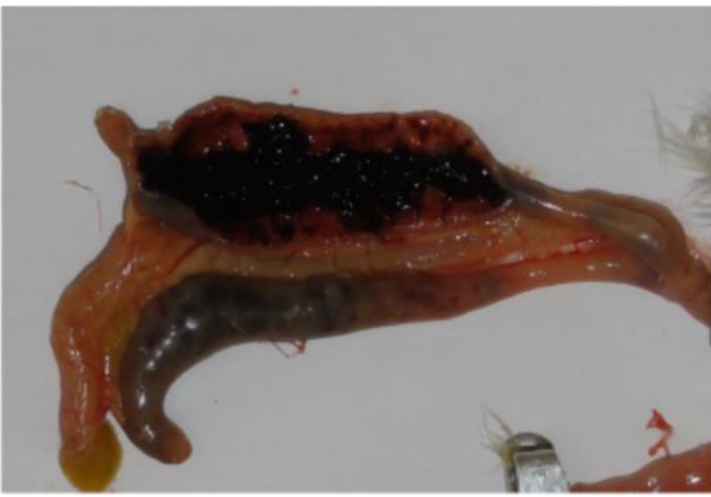

Fig. (8) Present hemorrhage in colon and cecum progressing to cores of coagulated blood in lumen of the cecum in pigeon infected by Eimeria spp.

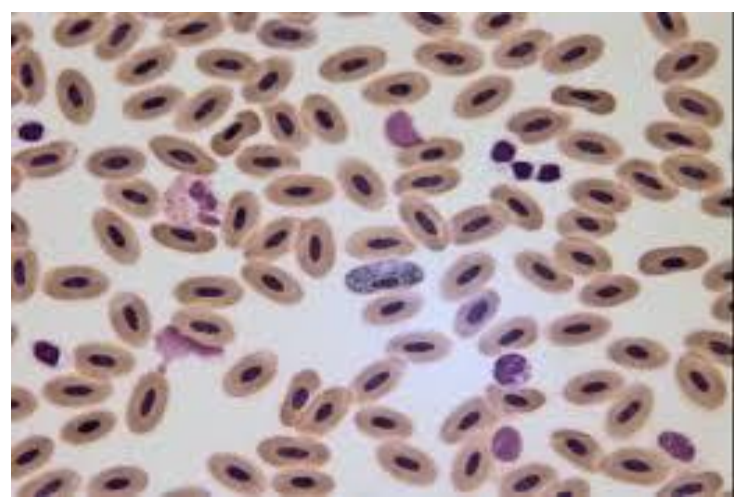

Fig. (10) Haemoproteus spp x100

12(16.2\%), among the pigeons. Other parasites encountered included; Raillietina echnobothrida. 10(13.5\%), Ascaridia colombae 9(12.1\%), Capillaria spp 9(12. 2\%), Argas persicus 8(10.8\%), Menopon gallinae 7(9.4\%), Columbicola columbae 7(9.5\%), Eimeria spp 6(8.1\%), Leucocytozoon spp 4(5.5\%), and Haemoproteus spp 2(2.8\%). (Table- 1 \& Table2)

Table 1: Prevalence of parasites which infect the pigeons in the city of Sharqat, Salah Al-Deen province.

\begin{tabular}{ccccc}
\hline & \multicolumn{2}{c}{ Males } & Females \\
\cline { 2 - 5 } Parasitic infestations & No. positive & $\%$ & No. positive & $\%$ \\
\hline Single infestation & 15 & 20.3 & 22 & 31 \\
\hline Mixed infestation & 17 & 23.1 & 19 & 25.6 \\
\hline
\end{tabular}


Table 2: Prevalence of the external and internal parasites which infect the pigeons (males\&females) in the Sharqat city, Salah Al-Deen province.

\begin{tabular}{cccccc}
\hline Parasitic species & Infected no. & $\begin{array}{c}\text { Positive no. } \\
\text { of male }\end{array}$ & $\%$ & $\begin{array}{c}\text { Positive no. } \\
\text { of female }\end{array}$ & $\%$ \\
\hline Helminthes & & & & & \\
\hline Raillietina tetragona & $\mathbf{1 2}$ & $\mathbf{5}$ & $\mathbf{6 . 8}$ & $\mathbf{7}$ & $\mathbf{9 . 4}$ \\
\hline Raillietina echnobothrida & $\mathbf{1 0}$ & $\mathbf{6}$ & $\mathbf{8 . 1}$ & $\mathbf{4}$ & $\mathbf{5 . 4}$ \\
\hline Ascaridia colombae & $\mathbf{9}$ & $\mathbf{4}$ & $\mathbf{5 . 4}$ & $\mathbf{5}$ & $\mathbf{6 . 7}$ \\
\hline Capillaria spp & $\mathbf{9}$ & $\mathbf{7}$ & $\mathbf{9 . 5}$ & $\mathbf{2}$ & $\mathbf{2 . 7}$ \\
\hline Ectoparasites & & & & & \\
\hline Argas persicus & $\mathbf{8}$ & $\mathbf{4}$ & $\mathbf{5 . 4}$ & $\mathbf{4}$ & $\mathbf{5 . 4}$ \\
\hline Menopon gallinae & $\mathbf{7}$ & $\mathbf{3}$ & $\mathbf{4}$ & $\mathbf{4}$ & $\mathbf{5 . 4}$ \\
\hline Columbicola columbae & $\mathbf{7}$ & $\mathbf{2}$ & $\mathbf{2 . 7}$ & $\mathbf{5}$ & $\mathbf{6 . 8}$ \\
\hline Coccidiosis & & & & & \\
\hline Eimeria spp & $\mathbf{6}$ & $\mathbf{2}$ & $\mathbf{2 . 7}$ & $\mathbf{4}$ & $\mathbf{5 . 4}$ \\
\hline Blood parasites & & $\mathbf{3}$ & $\mathbf{4}$ & $\mathbf{1}$ & $\mathbf{1 . 4}$ \\
\hline Leucocytozoon spp & $\mathbf{4}$ & $\mathbf{3}$ & $\mathbf{1 . 4}$ & $\mathbf{1}$ & $\mathbf{1 . 4}$ \\
\hline Haemoproteus spp & $\mathbf{2}$ & $\mathbf{5 1}$ & $\mathbf{5 0}$ & $\mathbf{3 7}$ & $\mathbf{5 0}$ \\
\hline Total grand & $\mathbf{7 4}$ & &
\end{tabular}

\section{DISCUSSION}

The results of this study reported about racing pigeons infection by Raillietina tetragona in both males \& female $12(16.2 \%)$ (Figure 1) similar to results the researchers (Sari et al., 2008). While others (Ashrafihelan et al., 2010) were reported in domesticated pigeons that results of Raillietina tetragona which is less than present for our study results our study found Raillietina echnobothrida 10 $(13.5 \%)$ (Figure 2) the result agreed with researchers (Radfar et al., 2012, Ghosh et al., 2014) while (Khezerpour and Naem, 2013) recorded 32\% infected pigeon with Raillietina echnobothrida. Raillietina is the most prevalent helminthes in pigeon, this information may be play dangerous role in poultry and may be of human health (Ferial et al., 2018). We also recorded a worm belong to Ascaridia colombae 9(12.1\%) (Figure 3). These observations agree with Foronda et al. (2004), while El-Dakhly et al (2016) reported $21 \%$ the pigeon infected with Ascaridia spp.

In the present study infection with Capillaria spp. was $9(12.2 \%)$ (Figure 4). The prevalence of Capillaria spp. was like that recorded by Baris et al. (2008) in Turkey, while (12.1\%). It was higher than that recorded by Khezerpour and Naem (2013) in domestic pigeons in Iran, but lower than those recorded by Ghosh et al. (2014) in Bangladesh $22 \%$ Capillaria infections were observed in pigeons along with Ascaridia colombae, causing cachexia and haemorrhagic enteritis (Abed et al., 2014). Our result showed that $8(10.8) \%$ of examined pigeon is infested with the larval stage of soft tick Argas persicus (Figure 5), it also Msoffe et al. (2010) reported in Tanzania that tick infestation were $12 \%$. Argas persicus can cause paralysis because it toxin produce and can also transmit a disease called spirochaetosis, which is a gut condition that leads to diarrhea (Ali et al., 2012). The study also recorded another different species of ectoparasites were identified: Menopon gallinae $7(9.4 \%)$ (Figure 6) and Columbicola columbae 7(9.5\%) (Figure 7). These species had been reported in several studies as the commonest and most important ectoparasites infestation of pigeon like (Mushi et al., 2000) and (Jahantigh et al., 2016). Similar reports have been documented from Sulaimani province, Kurdistan region/Iraq (Shadan et al., 2018) and Dhaka, Bangladesh (Aleya and Sabrina, 2011). These parasites suck the blood of infected pigeon which lead to pigeon emaciation and infestation the (AlBarwari and Isam, 2012). The prevalence rate of Eimeria spp. 6(8.1\%) (Figure 8) in this study and similar with Sivajothi et al (2014), while (Parsani et al., 2014) from India recorded the high infected rate with Eimeria spp (48.3\%) compared with the present study. Emirian which responsible for cause Coccidiosis usually runs without clear clinical manifestations, with affected pigeons look like healthy, but has watery diarrhea (Balicka-Ramisz and Pilarczyk, 2014). The study results determined the more common blood parasite found in pigeons were Leucocytozoon spp. 4(5.4\%), and Haemoproteus spp. 2(2.8\%) (Figures $9 \& 10$ ) which agreed with the studies done in (Al-Biatee, 2011, Hussein and Abdelrahim, 2016) found Haemaproteus spp. Infected the domestic. In other countries the researchers (Saleem et al., 2016, Sürsal et al., 2017) reported that the prevalence of this blood parasite was higher than that found in this study. Also (Samani et al., 2013) found a prevalence of $24 \%$ in Southwest Iran. 


\section{REFERENCES}

Abed, A.A.; Naji, H.A. and Rhyaf, A.G. (2014): Investigation study of some parasites infected domestic pigeon (Columba livia domestica) in Al-Dewaniya city. Journal of Pharmacy and Biological Sciences, 9: 13-20.

Adang, K.L.; Oniye, S.J.; Ezealor, A.U.; Abdu, P.A. and Ajanusi, O.J. (2008): "Ectoparasites of Domestic pigeon (Columba livia domestica, Linnaeus) in Zaria, Nigeria". Research Journal Parasitology, Vol. 3, pp. 2, pp. 79-84.

Al-Barwari, S. and Isam, S. (2012): The Parasitic Communities of the Rock Pigeon Columba livia from Iraq: Component and Importance. (Turkiye Parazitol Derg 2012; 36: 232-9).

Al-Biatee, S.T. (2011): Isolation and identification of some ectoparasites and haemoprotozoa in some species of family columbidae. M. Sc. Thesis, Colloge of Vet. Med., University of Baghdad.

Aleya, B. and Sabrina, S. (2011): Prevalence and seasonal variation of ectoparasite in pigeon, Columba liva (Gmelin, 1979) of Dhaka, Bangladesh. Bangladesh J Zool 39(2): 223230.

Al-Hubity, I.A. and Al-Habib, W.M.S. (1979): A survey of the helminth parasites of the domestic fowl (Gallus gallus domesticus) in Mosul district, Iraq. Mesopotamia J Agric; 14: 197-205.

Ali, M.B.; Ali, L.M. and Mostafa, R. (2012): Pathological study of parasitism in racing pigeons: An indication of its effects on community health. African Journal of Biotechnology. 11(59), pp.12364-12370

Al-Jumaily, W.T.; AL-Atar, M.A.; Al-Tae, A.R.; Mansour, A.D.; Jiad, J.H. and Abdul-Latif, H. (1989): The incidence of Salomenlla and serological evidence of Nwecastle disease in some wild birds from Baghdad area. JBSR., 20: 213-219.

Ashrafihelan, G.; Norozi, R. and Seyed-Hosein, N. (2010): An identification of helminth parasites and gastrointestinal infection domestic pigeon in Tabriz, Iran. Iranian Journal of Veterinary Research. 6(3): 52-57.

Balicka-Ramisz, A. and Pilarczyk, B. (2014). Occurrence of coccidia infection in pigeons in amateur husbandry. Diagnosis and prevention. Annals of Parasitology. 60: 93-97

Baris, S.; Karatepe, B.; Karatepe, M. and Murat, K. (2008): Parasites of domestic (Columba livia domestica) and wild (Columba livia livia) pigeons in Niğde, Turkey. Bull. Vet. Inst. Pulawy. 52, 551-554.

Charles, M.H. (1998): Dignostic Veterinary Parasitology. 2nd ed. Mosby, Elsevier, pp: 246-257.

El-Dakhly, K.M.; Mahrous, L.N. and Mabrouk, G.A. (2016): Distribution pattern of intestinal helminths in domestic pigeons (Columba livia domestica) and turkeys (Meleagris gallopavo) in Beni-Suef province, Egypt. J. Vet. Med. Res. 23(1), 112-120.

Ferial A. Alkharigy; Adnan S., El Naas and Abdulhakim, A. EL Maghrbi. (2018): Survey of parasites in domestic pigeons (Columba livia) in Tripoli, Libya Open Veterinary Journal. Vol. 8(4): 360-366.

Foronda, P.; Valladares, B. and Riveramedina, J.A. (2004): Parasites of Columba livia (Aves: Columbiformes) in Tenerife (Canary Islands) and theirrole in the conservation biology of the Laurel pigeons. Parasitology

Foronda, P.; Valladares, B. and Rivera-Medina, J.A. (2004): Parasites of Columba livia (Aves: Columbiformes) in Tenerife (Canary Islands) and their role in the conservation biology of the Laurel pigeons. Parasitol. 1: 311-316.

Ghosh, K.K.; Islam, M.S.; Sikder, S.; Das, S.; Chowdhury, S. and Alim, M.A. (2014): Prevalence of Ecto and Gastrointestinal Parasitic Infections of Pigeon at Chittagong Metropolitan Area, Bangladesh. J. Adv. Parasitol. 1(1), 9-11.

Ghosh, K.K.; Islam, M.S. and Sikder, S. (2014): Prevalence of ecto and gastrointestinal parasitic infections of pigeon at Chittagong metropolitan area,

Bangladesh. J Adv Parasitol. 1(1): 9-11.

Gilik, Y. and Arslan, M.O. (2011): "Blood parasites of wild Pigeon in Ankara District". Turk. J. Vet. Anim. Sci., Vol. 25, pp. 169- 172.

Hussein, N.M. and Abdelrahim, E.A. (2016): Haemoproteus Columbae Infection and its Histopathological Effects on Pigeons in Qena Governorate, Egypt. J. Pharm. Biol. Sci. (IOSRJPBS) 11(1), 79-90.

Jahantigh, M.; Esmailzade dizaji, R. and Teymoori, $Y$. (2016): Prevalence of external parasites of pigeon in Zabol, southeast of Iran J Parasit Dis (Oct-Dec 2016) 40(4): 1548-1551.

Khezerpour, A. and Naem, S. (2013): Investigation on Parasitic Helminths of Gastrointestinal, Liver and Lung of Domestic Pigeons (Columba livia) in Urmia, Iran. Int. J. Livest. Res. 3(3), 35- 41.

Klein, R.; Bartel, M.; Paulus, M.; Quack, M.; Tarricone, K.; Wagner, G.; Ball, M.; Rüdel, H. and Schlüter, C. (2008): Pollution of urban industrial ecosystems in Germany the use of bioindicators from different trophic levels. Environ Bioindic 3: 15-19.

Marques, S.M.; De Quadros, R.M.; Da Sailva, C.J. and Baldo, M. (2007): Parasites of pigeons (Columba livia) in urban areas of Lages, Southern Brazil. Parasitol. Latino Amr., 62: 183-187.

McDougald, LR. (2003): In: Saif YM. (chief editor) Barnes HJ, Glisson JR, Fadly AM, 
McDougald LR, and Swayne D. Diseases of poultry. 11th ed, Iowa state press, Ames, Iowa.; pp.1006-1008.

Msoffe, P.L.M.; Muhairwa, A.P.; Chiwanga, G.H. and Kassuku, A.A. (2010): A study of ecto and endoparasites of domestic pigeons in Morogoro Municipality, Tanzania. Afr. J. Agric. Res. 5: 264-267.

Mushi, E.Z.; Binta, M.G.; Chabo, R.G.; Ndebele, R. and Panzirah, R. (2000): Parasites of domestic pigeons (Columba livia domestica) in Sebele, Gaborone, Botswana. J S Afr Vet Assoc. 71: 249-50

Natala, A.J.; Asemadahun, N.D.; Okubanjo, O.O.; Ulayi, B.M.; Owolabi, Y.H; Jato, I.D. and Yusuf, K.H. (2009): "A Survey of Parasites of Domesticated Pigeon (Columbalivia domestic) in Zaria, Nigeria". International Journal of Soft Computing, Vol. 4, No. 4, pp. 148-150.

Parsani, H.R.; Momin, R.R.; Lateef, A. and Shah, N.M. (2014): Gastro-intestinal helminths of pigeon (Columba livia) in Gujarat, India. Egyptian Journal of Biology. 16: 63-71.

Radfar, M.H.; Fathi, S.; Asl, E.N.; Dehaghi, M.M. and Seghinsara, H.R. (2011): "Asurvey of parasites of Domestic Pigeons (Columbia livia domestica) in South Khorasan", Iranian Journal of Veterinary Research, Vol. 4, No. 1, pp. 18-23.

Radfar, M.H.; Norouzi, A.E. and Rezaei Seghinsara, H. (2012): Biodiversity and prevalence of parasites of domestic pigeons (Columba livia domestica) in a selected semiarid zone of South Khorasan, Iran. Trop Anim Health Prod.;44(2): 225-229.

Saleem, M.H.; Khan, M.S.; Chaudry, A.S. and Samad, H.A. (2008): Prevalence of Trichomoniasis in Domestic and Wild Pigeons and Its Effects on Hematological Parameters. Pakistan Vet. J. 28(2), 89-91.

Samani, A.D.; Khairtabadi, K.P. and Samani, A.D. (2013): Prevalence and Rate of Parasitemia of Haemoproteus columbae in Columba livia domestica in Southwest of Iran. Iran. J. Parasitol. 8(4), 641-644.
Sari, B.; Karatepe, B. and Karatepe, M. (2008): Parasites of domestic pigeon (Columba livia domestica) and wild (Columba livia livia) pigeons in Nigde, Turkey. Bull Vet Inst Pulawy. 52: 551-554.

Sari, B.; Karatepe, B.; Karatepe, M. and Kara, M. (2008): Parasites of domestic (Columba livia domestica) and wild (Columba livia livia) pigeons in NIĞDE. Turkey Bull. Vet. Last. Palawy, 52: 551-554.

Shadan, H.A.; Aram, A.M.; Nahla, M.S. (2018): Study of ecto and haemo parasites in domestic pigeons (Columba livia domestica) in Sulaimani province, Kurdistan region/Iraq. Jour. of Zan. Sul. (JZS) (20-1): 37-44.

Sivajothi, S.; Reddy, B.S. and Rayulu, V.C. (2014): Intestinal coccidiosis infection in domestic pigeon. International Journal of Biological Research. 2(2): 48-50.

Soulsby, E.J.L. (1982): "Helminth, Arthropods and Protozoa of Domesticated Animals". $7^{\text {Th }}$ Ed. Bailiere Tindall and Cassel. Ltd. London, pp. 763-765.

Soulsby, J.L. (1986): "Genus: Haemoproteus Kruse, 1890. In: Soulsby, E.J.L. (ed.) Helminths, Arthropods and Protozoa of domesticated animals ( $\left.7^{\text {th }} \mathrm{Ed}\right)$ ". Baillière Tindall, London: pp. 700-705.

Sürsal, N.; Atan, P.; Gökpınar, S.; Duru, Ö.; Çakmak, A. and Yıldız, K. (2017): Prevalence of Haemoproteus spp. in Tumbler Pigeons (Columba livia domestica) in Kirikkale Province, Turkey. Turkiye Parazitol Derg. 41(2), 71-75.

Vazquez, B.; Esperon, F.; Neves, E.; Lopez, J.; Ballesteros, C. and Munoz, V.M.J. (2010): Screening for several potential pathogens in feral pigeons (Columba livia) in Madrid. Acta Veterinaria Scandinavica. 52: 45-50.

Zangana, M.F. (1982): Study on the Parasites of Domestic Pigeon Columba Livia domestica in Nineveh and Some Area of Erbil and Dohuk Provinces. M.Sc. Thesis, Mosul University, Iraq.

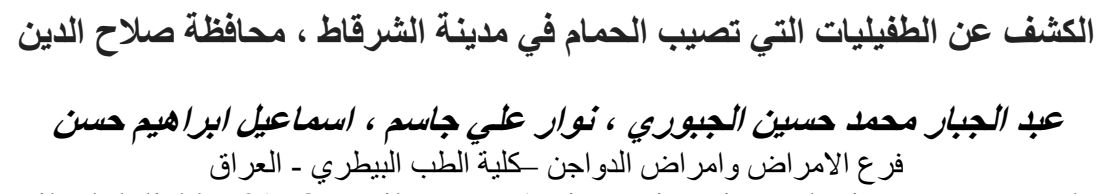

Email: abduljabbar81n@gmail.com Assiut University web-site: www.aun.edu.eg

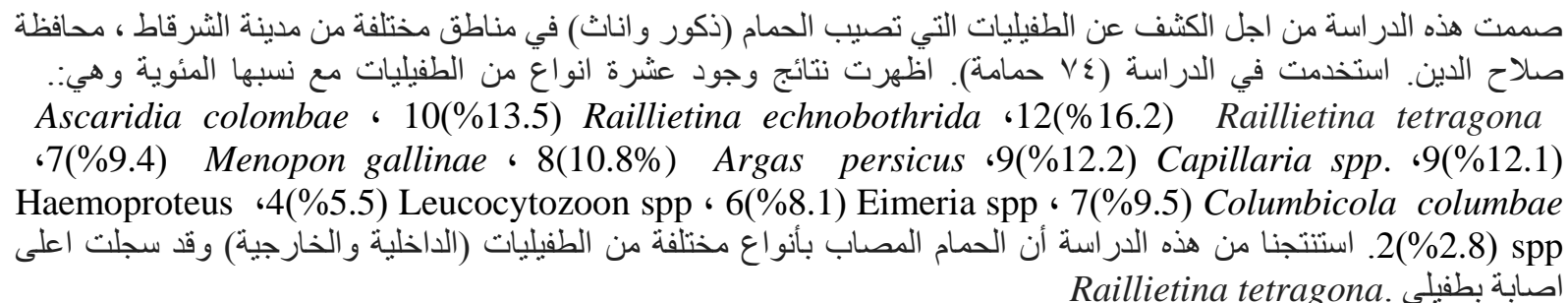

